\title{
SPIRITUALISASI KEILMUAN: Mengkonstruksi Peradaban Intelektual Muslim Abad Ke-21
}

\author{
Moh. Miftahusyaian \\ Fakultas Tarbiyah UIN Maulana Malik Ibrahim Malang. Jalan Gajayana No. 50 Malang \\ Telp.081252233661, e-mail: arkan06@gmail.com
}

Abstract

Western scholars who separate between science and religion have brought people in the final point of civilization. Therefore, the duty of Moslem scholar in the 21 th century is to rebuild the spiritual intellectual integrity in the frame of science and civilization. The main responsibility of Moslem scholars, nowadays, in reaching the brightness of life is reconstructing science paradigm by relocating God as the main stream of thought. The bright time of Madinah civilization is the starting point of the glory of Islamic civilization which successfully has entered all over the world. Therefore, intellectual orientation which has become Moslem's responsibility is to reform the principles of Madinah civilization to be reconstructed to the present time. This is very important issue as Madinah civilization has not established yet that will be possible for Moslem scholars can speak much about the 21th century civilization. At the beginning of Islam period, the fight proposed by Moslem scholars was deconstructed the Jahiliyah's way of thinking, furthermore, the great jihad of Moslem scholars in the present time is reconstructing the scientific way of thinking which is currently empirical-minded. Moreover, the Moslem scholar's responsibility is to present spiritualism in scientific discourse. The integration of science and religion has become conceptualization of his science, hence, al Quran will be always the eternal source of science.

Key words: spritual, intellectual, civilization, and science 


\section{Pendahuluan}

Setiap generasi mempunyai beban tanggung jawab yang berbeda sesuai dengan kondisi sosio-historis yang melingkupinya. Pada masa generasi awal Islam, tanggung jawab sejarah yang diemban adalah membumikan ajaranajaran Islam dalam domain segala aspek praktik sosial. Tugas ini secara paripurna telah dilakukan oleh Muhammad Sang Nabi dengan dibantu oleh para sahabat. Muhammad, secara cerdas telah mewujudkan konseptualisasi al Quran dalam bentuk sunnah dan praktik keseharian yang aplikatif sesuai dengan kadar kebudayaan yang berlaku pada masa itu. Uniknya, apa yang telah diwujudkan oleh Muhammad tersebut merentang jauh sampai saat ini, menembus ruang dan waktu, dan bahkan berlaku di wilayah geografis dengan keragaman kadar kebudayaan.

Generasi selanjutnya, para Khulafaur Rasyidin, mempunyai tanggung jawab untuk melestarikan apa yang telah dimaterialkan oleh Muhammad, sekaligus menebarkannya ke seluruh penghujung dunia. Tanggung jawab ini diteruskan oleh para khalifah berikutnya sampai pada masa runtuhnya kekhalifahan Islam. Secara resmi, kekhalifahan Islam runtuh pada tanggal 3 Maret 1924 yang ditandai dengan beralihnya kekuasaan Turki Utsmaniyah ke tangan Mustafa Kemal "Attaturk" Pasha. Turki berubah menjadi Republik sekuler. Pada masa-masa tersebut, umat Islam telah menghiasi dunia dengan kecemerlangan kebudayaan yang merentang meliputi wilayah Timur-Tengah, Asia Selatan, Asia Timur, Asia Tenggara, Eropa Tenggara, wilayah Erasia dan Rusia.

Sekarang, generasi pasca runtuhnya kekhalifahan, dimana matahari peradaban telah berpindah ke Barat, kaum muslim khususnya mereka yang terpelajar mempunyai amanah untuk merekonstruksi paradigma keilmuan yang saat ini sedang mengalami keruntuhan spiritual. Spiritualisasi keilmuan adalah jihad akbar yang menjadi amanah sejarah kaum muslim di abad ke-21 untuk kembali menghantarkan umat manusia pada kecemerlangan peradaban.

Tulisan ini, mencoba menyajikan argumentasi bahwa ilmu pengetahuan tanpa sentuhan spiritual adalah keilmuan yang "buta" dan menghancurkan peradaban. Usaha intelektual Barat untuk menjauhkan ilmu pengetahuan dari Tuhan ternyata telah membawa manusia pada titik nadir peradaban. Tugas intelektual muslim di abad ke-21 ini adalah mengharmonikan spiritual dan intelektual dalam membangun bingkai keilmuan dan peradaban. 


\section{Historisasi Ilmu Pengetahuan Modern}

Memperbincangkan ilmu pengetahuan modern, kita tidak bisa mengesampingkan Benua Eropa (baca: Eropa Barat) yang menjadi kiblat sekaligus episentrumnya. Berawal dari wilayah benua inilah, seluruh kerangka paradigma filsafat, ilmu pengetahuan, dan sains terapan yang sekarang dikaji dan dipelajari di universitas-universitas seluruh dunia pertama kali dikembangkan, dan dalam gerak laju sejarahnya di kemudian hari, Eropa Barat menjadi kiblat pengembangan ilmu pengetahuan modern. Gerakan revolusi intelektual bertajuk Renaissance dan Humanisme yang mempunyai andil dan tanggung jawab besar dalam pengembangan ilmu pengetahuan modern tersebut, yang tumbuh pesat sampai saat ini.

Hadirnya Renaisans dan Humanisme secara historis merupakan bentuk kekecewaan kaum intelektual Eropa Barat atas kegagalan gereja dalam menjelaskan gejala-gejala alam dan fenomena sosial. Seperti telah kita ketahui, pada abad pertengahan Eropa, dengan gereja bersumber pada kitab injil yang mempunyai kekuasaan luar biasa dalam menata kehidupan masyarakat, termasuk dalam hal indoktrinasi ilmu pengetahuan. Hal ini dapat ditelusuri pada dokumen Donation of Constantine, yang menegaskan bahwa Paus adalah wakil Tuhan di bumi. Di samping itu, dalam dokumen tersebut juga terdapat pernyataan Konstantin Yang Agung untuk memindahkan seluruh kekuasaan Kekaisaran Roma Suci kepada Gereja Vatikan, termasuk hak untuk memilih dan memecat para Raja. Tetapi, dalam perjalanan sejarahnya ternyata interpretasi ilmu pengetahuan yang dirujuk dari kitab suci injil tidak sepenuhnya bisa dijadikan dasar pijakan ilmiah untuk menjelaskan gejala-gejala alam dan fenomena sosial, apalagi mengembangkannya. Kasus Copernicus dengan paham heliosentrisnya yang berseberangan dengan doktrin geosentrisme Gereja-Vatikan, merupakan salah satu bukti bahwa interpretasi filsafat scholastik gereja tidak bisa diterima secara ilmiah. Akibat dari kegagalan gereja mengembangkan ilmu pengetahuan, masyarakat Eropa mengalami kebuntuan berpikir, struktur masyarakat stagnan, takhayul berkembang dan jauh dari peradaban. Dalam sejarah, masa itu dikenal dengan istilah abad kegelapan (Age of Darkness). Ada baiknya disimak penuturan Saunders berikut ini:

"Hingga tahun 1004 M, Barat (maksudnya Eropa-pen) merupakan daerah miskin, terbelakang dan buta huruf. Mereka (berusaha) mempertahankan diri dari serangan bangsa Bar-Bar yang terjadi di darat dan di laut..." (Saunders, 1994: 23). 
Pernyataan yang hampir senada juga diungkapkan berikut(Lauer, 1989: 254):

“...Selama abad pertengahan, kalangan pendeta menggunakan ideologi keagamaan sebagai alat untuk mendapatkan kekuasaan lebih besar dan karena itu menghalangi terjadinya perubahan. Kemajuan ekonomi diperlambat dengan menyatakan bahwa membungakan uang sebagai perbuatan riba yang penuh dengan dosa. Surplus kekayaan cenderung disalurkan untuk membeli barangbarang perhiasan, aktivitas sopan santun, membangun bangunan keagamaan dan istana. Dengan kata lain, surplus kekayaan tidak ditanamkan dalam usaha perdagangan dan industri melainkan tersedot ke dalam aktivitas keagamaan yang tidak produktif yang diyakini akan menimbulkan kasih sayang Tuhan. Akibatnya, sekitar penghujung abad pertengahan, teknik penyediaan air minum dan sanitasi (yang telah dibangun orang Romawi jauh sebelumnya) masih belum digunakan. Kota-kota dipadati oleh bangunan keagamaan yang sering boros, kotor, jalan raya tanpa perencanaan dan struktur bangunan yang sembrono...".

Gambaran di atas merupakan kondisi Eropa jauh sebelum terjadinya Renaisans dan Humanisme. Ketika itu, London, Paris, dan Amsterdam hanyalah kota-kota kecil, dan bahkan terlalu kecil untuk dapat dilihat di peta.

Di saat Eropa mengalami masa kegelapan abad pertengahan, di Benua lain (Asia) muncul peradaban baru yang sedang tumbuh dan berkembang menuju puncak keemasannya. Peradaban baru ini, sama persis dengan yang terjadi di Eropa pada masa itu merupakan bentuk peradaban ideasional. Jika di Eropa abad pertengahan sumber pengkajian ilmu pengetahuan adalah kitab suci injil, maka di Asia ketika itu adalah kitab suci al Quran. Kedua peradaban ideasional ini hadir dalam rentang kesejarahan yang hampir bersamaan tetapi menghasilkan sentuhan akhir (finishing touch) peradaban yang berbeda, bahkan bertolak belakang. Eropa Barat terpuruk dalam kubangan kegelapan. Sementara itu, Asia Barat menjelma menjadi peradaban agung. Di puncak keemasannya, peradaban Asia Barat ini menghasilkan universitas-universitas terbaik dunia. Ilmu pengetahuan berkembang pesat. Ilmu hitung (aljabar), kimia, astronomi, fisika, arsitektur, sastra, kedokteran, etika (akhlak atau adab) berkembang menjadi pilar penyangga peradaban. Kondisi keemasan peradaban Asia Barat (Islam) ini oleh Saunders digambarkan sebagai peradaban yang mampu menghasilkan kedamaian dan keamanan intern (Saunders, 1994: 52).

Kemegahan peradaban Asia Barat ini lambat-laun mempengaruhi peradaban Eropa. Gagasan intelektual sebagai produk kebudayaan Asia Barat banyak dipelajari oleh para intelektual Eropa pada masa itu sekaligus membentuk image baru masyarakat Eropa tentang dunia. Eropa yang ketika itu masih terbelakang banyak belajar dari peradaban Asia Barat ini, bahkan 
dalam hal mandi pun, orang Eropa belajar dari peradaban Islam. Kontribusi besar peradaban Asia Barat (Islam) terhadap kemajuan peradaban Eropa, secara jelas dideskripsikan sebagai berikut (Watt, 1972: 84):

(Ketika kita mencermati segala bentuk konfrontasi antara Kristen dan Islam pada abad pertengahan, jelas bahwa pengaruh Islam terhadap Umat Kristen Barat adalah lebih besar daripada yang selama ini disadari. Islam tidak hanya telah memberi begitu banyak produk material dan penelitian teknologi pada Eropa Barat; Islam juga tidak hanya telah menstimulasi Eropa secara intelektual dalam bidang sains dan filsafat; tetapi (lebih dari itu-pen) Islam telah memprovokasi Eropa ke dalam pembentukan sebuah image baru tentang dirinya sendiri. Karena Eropa selama ini terlalu bereaksi (antipasti-pen) melawan Islam, ia menganggap remeh pengaruh kaum Saraken serta terlalu melebih-lebihkan ketergantungannya pada warisan Yunani dan Romawi. Jadi saat ini, tugas bagi kita, masyarakat Eropa Barat, dalam rangka menuju ke dalam era "satu dunia", adalah mengoreksi kesalahan sudut pandang ini dan sekaligus memberi penghargaan yang penuh atas hutang kita terhadap Arab dan dunia Islam)

Salah satu kontribusi nyata peradaban Timur (Asia Barat atau Islam) terhadap perkembangan ilmu pengetahuan Eropa Barat adalah konsep angka nol (baca: titik), dapat dijelaskan bahwa $\mathrm{Nol}(0)$ dalam konsep ilmu hitung Arab ditulis dengan titik $(\bullet)$, untuk menghilangkan kesan bahwa ilmu hitung Eropa dipengaruhi oleh Islam maka diganti dengan simbol Nol (0). Secara lengkap urutan angka dari $1 \mathrm{~s} / \mathrm{d} 9$ dalam sistem Arab adalah: • I r Y Eo TV^9 merupakan konsep dasar bagi ilmu hitung aljabar yang mana kata al Jabbar diambil dari salah satu nama-nama indah (al Asma' al Husna) Allah yang berarti Maha Perkasa. Contoh operasi al Jabbar sederhana sebagai berikut: $2+2=$ $3+1=4+0=2 \times 2=4 \times 1=4$. Ilmu hitung al Jabbar dalam tingkatan yang lebih tinggi menghasilkan operasi penghitungan yang jauh lebih rumit dan canggih dibandingkan ilmu hitung ala Romawi yang diwarisi oleh masyarakat Eropa abad pertengahan (Inggris: Algebra). Selama dalam kekuasaan hegemoni gereja, Eropa mewarisi ilmu hitung ala Romawi yang tidak mengenal angka nol atau titik. Hal ini menyebabkan ilmu hitung tidak bisa dioperasikan secara sempurna dan berdampak luas pada stagnansi ilmu pengetahuan.

Berpijak dari paparan historis di atas, dapat disimpulkan bahwa terdapat dua faktor utama yang mendorong terjadinya revolusi intelektual di benua biru Eropa yang menjadi dasar pijakan ilmu pengetahuan modern, yaitu:

1. Faktor Internal, yakni akibat kegagalan gereja, sebagai pemegang tunggal kebenaran, dalam menjelaskan gejala-gejala alam dan fenomena-fenomena sosial. Hal inilah yang mendorong adanya gerakan Renaisans dan Humanisme. 
Renaisans sendiri dimaknai sebagai kelahiran kembali keemasan zaman kuno, artinya pada masa itu terdapat sebuah komitmen kolektif masyarakat Eropa Barat untuk kembali pada masa keemasan Yunani dan Romawi kuno yang telah melahirkan tokoh-tokoh pemikir seperti Plato, Aristoteles, Sokrates dan Archimides. Sedangkan Humanisme adalah sebuah gerakan intelektual yang memusatkan pemikirannya pada manusia (human) dan dunia (world). Gagasan-gagasan tentang Tuhan, hari akhir dan surga bukan menjadi pusat pemikiran karena dianggap terlalu abstrak dan tidak bisa diverifikasi kebenarannya secara ilmiah (empiris). Akibat gerakan Renaisans dan Humanisme ini, ilmu pengetahuan "dicerahkan" dari hegemoni Tuhan dan agama. Di Eropa, post-Renaissance sampai sekarang melahirkan sebuah mainstream bahwa, intelektualitas dan spiritualitas adalah dua hal yang terpisah, tak bisa dipadukan.

2. Faktor Eksternal, yakni pengaruh yang disebabkan oleh dinamika yang terjadi di benua lain, Asia Barat. Peradaban Asia Barat mendorong intelektual Eropa untuk pergi ke Timur mendalami ilmu pengetahuan. Mekipun demikian, akibat trauma terhadap hegemoni agama, para intelektual Eropa ini hanya mengambil wujud hardware ilmu pengetahuan dari peradaban Asia Barat (Islam) seperti: ilmu hitung aljabar, ilmu arsitektur, teknologi, etika, ilmu kesehatan, ilmu kemasyarakatan, dan sebagainya. Namun, bentuk software keilmuan Islam seperti: konsep ketuhanan (pure monotheism), tasawuf (asketisme) dan sistem ritual upacara keagamaan tidak diambil. Adapun tentang monotheism Islam ini, Betrand Russel dalam buku A History of Western Philosophy, menjelaskan: "Agama Nabi merupakan monotheism sederhana, yang tidak dibuat rumit oleh teologi trinitas dan inkainasi. Nabi tidak pernah mengklaim bahwa dirinya adalah Tuhan, demikian pula para pengikutnya..." (Madjid, 1995: 32).

Kalau toh mengambil bentuk software keilmuan Islam, yang diambil adalah sistem filsafat yang bersifat rasionalistik empiris, seperti: filsafat aliran Mu'tazillah, sebagian pemikiran Ibnu Farabi, Ibnu Sina (Avicenna), Ibnu Khaldun dan Ibnu Rusyd (Averoes).

Kedua faktor itulah yang membentuk sistem ilmu pengetahuan Eropa atau lebih luasnya dunia Barat post-Renaissance, yakni dengan memadukan semangat anti-Tuhan (dan karenanya juga anti agama) dengan sistem hardware ilmu pengetahuan Asia Barat (Islam). Oleh karena itu, wajar jika dalam buku-buku teks resmi ilmu pengetahuan 
Eropa modern tidak pernah disinggung diskusi tentang Tuhan. Cara berpikir Cartesian sangat melekat pada benak peradaban Eropa, yang masih berpengaruh sampai sekarang. Filsafat Cartesian merujuk pada seorang tokoh bernama Des Cartes, Bapak Rasionalisme Eropa sekaligus pendukung utama gerakan Renaisans dan Humanisme. Ungkapannya yang terkenal adalah Cogito ergo Sum (aku berpikir maka aku ada).

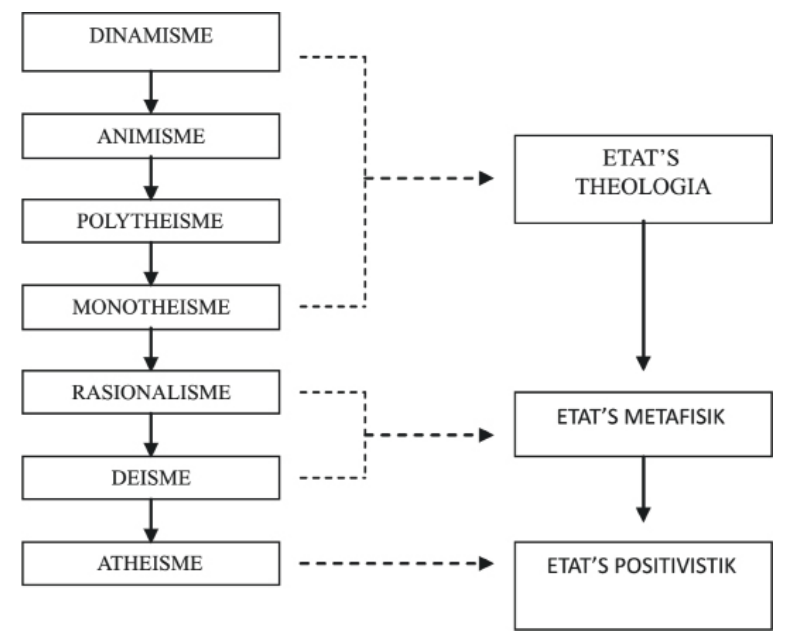

Gambar 1. Bagan Sejarah Antropologi Teologi vis a vis evolusi masyarakat Comte

Ilmu pengetahuan positif inilah yang menjadi argumentasi ilmu pengetahuan modern bahwa intelektualitas tidak bisa dipadukan dengan spiritualitas. Perbincangan tentang Tuhan, surga, neraka, dan takdir, yang banyak terekam dalam teks-teks Kitab Suci keagamaan adalah sesuatu yang non-rasional, jauh dari kaidah-kaidah ilmiah (dan oleh karenanya tidak bisa dikategorikan sebagai ilmu pengetahuan). Agama (dan juga Tuhan) tidak lebih dari sekadar hasil olah cipta pemikiran manusia (masyarakat) dalam merespon gejala-gejala alam. Manusia yang lemah, bodoh dan tertindas membutuhkan sosok yang bisa disembah untuk menenangkan hatinya. Oleh karena itu, agama hanya tumbuh pada masyarakat-masyarakat yang tertindas dan tak berbudaya. Marx (Marx, 2000: 165-166) menegaskannya sebagai berikut: "Agama adalah keluh-kesah makhluk tertindas, jiwa dari suatu dunia yang tak berjiwa, sebagaimana ia merupakan spirit dari situasi yang tanpa spirit. Agama adalah candu bagi rakyat."

Semakin tinggi tingkat kecerdasan (intelektualitas) manusia atau semakin 
berbudaya sebuah masyarakat maka dia akan semakin sadar bahwa setiap gejala-gejala alam mengikuti ritme hukum-hukum sains-positif, bukan diatur oleh sosok supra-inderawi yang bernama Tuhan.

\section{Perkembangan Mutakhir Ilmu Pengetahuan}

Penulis telah menjelaskan secara historis pembentukan kerangka dasar ilmu pengetahuan modern, yang secara tegas melepaskan diri dari pengaruh spiritualitas. Hal ini menghasilkan ilmu pengetahuan anti-Tuhan dan karenanya anti-spiritualitas.

Namun, temuan atau konseptualisasi ilmu pengetahuan diparuh akhir abad ke-20 dan memasuki abad ke-21 menghasilkan fakta yang bertolak belakang. Tuhan yang sejak post-Renaissance dihabisi, diragukan dan digugat keberadaannya oleh para ilmuwan, di abad ke-21 ini memperteguh eksistensinya justru oleh temuan atau konseptualisasi mutakhir ilmu pengetahuan. Lebih dari itu, semakin kompleks dan rumitnya permasalahan dunia mempertegas bahwa manusia kehilangan kendali dalam mengelola kehidupan.

Schumacher menjelaskan bahwa beberapa orang tidak lagi berang kalau diberitahu bahwa pemulihan harus datang dari dalam. Sangkaan bahwa segala sesuatu adalah "politik" dan bahwa pengaturan kembali "sistem" secara radikal akan memadai untuk menyelamatkan peradaban, tak lagi dianut dengan fanatisme yang sama seperti dua puluh lima tahun lampau, di mana-mana di dunia modern sekarang terdapat percobaan-percobaan gaya hidup baru dan kesederhanaan secara sukarela; kesombongan ilmu-ilmu materialistik telah berkurang, dan bahkan adakalanya orang telah bertenggang hati bila nama Tuhan disebut di dalam pergaulan yang sopan. Harus diakui bahwa beberapa di antara perubahan pikiran ini pada mulanya tidak berasal dari wawasan rohani, melainkan dari kecemasan materialistik yang ditimbulkan oleh krisis lingkungan, krisis bahan bakar, ancaman akan krisis bahan makanan dan petunjuk-petunjuk akan datangnya krisis kesehatan. Menghadapi semua ancaman ini dan banyak lagi lainnya kebanyakan orang masih percaya kepada "kepastian teknologi". Jika kita dapat mengembangkan energi peleburan (fusion energy), kata mereka, kesulitan-kesulitan bahan bakar akan terpecahkan; jika kita dapat menyempurnakan proses merubah minyak menjadi protein yang dapat dimakan, kesulitan bahan makanan dunia akan dipecahkan; dan pengembangan obat-obatan pastilah akan sanggup menghindarkan setiap ancaman dari krisis kesehatan dan sebagainya.

Serempak dengan itu, kepercayaan kepada kemahakuasaan manusia kini 
telah menipis. Bahkan jika semua masalah "baru" dapat dipecahkan dengan rumus-rumus teknologi, keadaan yang sia-sia, kekalutan dan kebejatan (moral) akan tetap. Keadaan ini telah ada sebelum krisis-krisis yang ada sekarang menjadi gawat dan ia tidak akan pergi dengan sendirinya. Semakin banyak orang yang mulai menyadari "percobaan modern" telah gagal. Percobaan itu mendapatkan rangsangannya mula-mula dari apa yang disebut evolusi model Descartes, yang dengan logika yang degil, memisahkan manusia dari tingkat-tingkat yang lebih tinggi, yang dapat mempertahankan keinsaniannya. Manusia menutup gerbanggerbang surga terhadap dirinya sendiri dan mencoba dengan daya kerja dan kecerdikan yang besar sekali, mengurung diri mereka di bumi. Kini ia mulai mengetahui bahwa bumi hanyalah tempat persinggahan sementara. Sehingga suatu penolakan untuk mencapai surga berarti tak sengaja turun ke neraka.

Mungkin saja dapat dibayangkan hidup tanpa gereja, tapi mustahil hidup tanpa agama (religion), yaitu tanpa kerja sistematis, memelihara hubungan dengan dan berkembang ke arah tingkat-tingkat yang lebih tinggi ketimbang tingkat "kehidupan sehari-hari," dengan segala kesenangan dan kepahitannya, sensasi dan kepuasannya, kehalusan dan kekasarannya dan sebagainya. Percobaan modern untuk hidup tanpa agama telah gagal, dan sekali kita memahami hal ini, kita pun lalu tahu apa sesungguhnya tugas "pasca modern" kita.

Singkatnya, eksperimen modern untuk menata kehidupan tanpa Tuhan telah mengalami kegagalan yang direkam secara provokatif sebagai berikut (Capra, 2000: 9):

"Adalah suatu tanda zaman yang mengejutkan bahwa orang-orang yang seharusnya ahli dalam berbagai bidang tidak lagi mampu menyelesaikan masalah-masalah mendesak yang telah muncul di dalam bidang keahlian mereka. Ekonom tidak mampu memahami inflasi, onkolog sama sekali bingung tentang penyebab kanker, psikiater dikacaukan oleh schizofrenia, polisi tak berdaya menghadapi kejahatan yang meningkat, dan lain sebagainya".

Di samping adanya fakta bahwa permasalahan dunia semakin kompleks dan rumit, ilmu pengetahuan yang selama ini habis-habisan memusuhi Tuhan, dalam perkembangannya justru menyajikan bukti yang berbalik 180 derajat. Temuan-temuan kekinian ilmu pengetahuan menunjukkan bukti bahwa Tuhan adalah nyata adanya. Temuan-temuan itu, antara lain:

1. Untuk melakukan pembuktian bahwa alam semesta ini terjadi secara tiba-tiba [di waktu $(\mathrm{t})=0$ dengan Volume $(\mathrm{V})=0$ dan kerapatan $=$ tak terhingga $\left({ }^{\sim}\right)$ ] yang mana gagasan ini merupakan implikasi dari teori kosmologi modern dentuman besar (Big Bang Theory), yang bangunan teoritisnya merupakan 
penyempurnaan dari Hukum Gravitasi Newton, Hukum Relativitas Einstein dan Mekanika Kuantum Stephen Hawking. Pada rentang tahun 1989-1992 tim Berkeley dan National Aeronautics and Space Administration (NASA) melakukan serangkaian uji coba dan penelitian untuk memetakan langit dan mengukur radiasi latar kosmik dengan menggunakan satelit Cosmic Background Explorer (COBE), selanjutnya penelitian ini dikenal dengan proyek COBE (I dan II). Dari penelitian ini dijelaskan bahwa Radiasi Latar Alam Semesta (kosmik) adalah radiasi panas yang baru mulai dipancarkan 350.000 tahun setelah peristiwa Big Bang. Radiasi ini, yang dipancarkan ke segenap penjuru di alam semesta, menampilkan potret sekilas dari jagad raya berusia 350.000 tahun, dan dapat dipandang sebagai fosil [sisa-sisa peninggalannya] di masa kini. Radiasi ini, yang pertama kali ditemukan pada tahun 1965, diakui sebagai bukti mutlak bagi Big Bang yang disertai berbagai pengkajian dan pengamatan, dan diteliti secara sangat mendalam. Dari penelitian ini dihasilkan fakta bahwa terdapat gelombang-gelombang kecil pada Radiasi Latar Alam Semesta yang membenarkan kurva radiasi termal Planc. Penelitian ini mendukung gagasan (theory) bahwa alam semesta terbentuk secara tiba-tiba (Big Bang Theory), yang sekaligus mengisyaratkan bahwa semesta (termasuk segala isinya) "ada" dari "ketiadaan," yang merupakan indikasi adanya campur-tangan Individu Cerdas (Individu Cerdas inilah yang diidentikkan dengan istilah Tuhan) dalam mendesain setiap fase evolusi semesta. Dalam konteks ini, hukum kekekalan materi tidak berlaku. Hasil temuan proyek COBE ini kemudian dikonfirmasikan pula oleh Observatorium Anglo-Australia di negara bagian New South Wales, Australia dan Observatorium Apache Point di New Mexico, Amerika Serikat.

2. Penelitian kontemporer bidang Biologi Molekuler di tingkatan sel menunjukkan fakta yang mengejutkan. Sel sebagai dampak teori Evolusi Darwin sampai pada akhir abad ke-20 masih dipahami sebagai sesuatu yang sangat sederhana. Haeckel, mendefinisikan sel sebagai: "Gumpalan kecil sederhana yang terbentuk dari kombinasi karbon”. Namun, penemuan mutakhir biologi molekuler menunjukkan fakta bahwa sel mempunyai sistem jaringan yang sangat rumit dan kompleks. Mengenai hal ini, Denton seorang ahli Biologi Molekuler menjelaskannya sebagai berikut:

"Untuk memahami realitas kehidupan sebagaimana yang diungkap biologi molekuler, kita harus memperbesar sel seribu juta kali sampai diameter dua puluh kilometer dan menyerupai kapal terbang raksasa yang cukup besar untuk menutup kota besar seperti London atau New York. Apa yang kemudian kita 
saksikan adalah sebuah bangunan dengan kerumitan yang tak tertandingi dan desain adaptif. Pada permukaan sel ini kita akan melihat jutaan lobang, seperti rongga penghubung pada pesawat antariksa raksasa, membuka dan menutup untuk memungkinkan arus pengiriman barang yang terus ke luar dan ke dalam sel. Jika kita memasuki salah satu lubang ini kita akan mendapati diri kita dalam dunia dengan teknologi paling canggih dengan kerumitan yang menakjubkan" (Denton, 1986: 60).

Kerumitan dan kompleksitas sel ini tersusun dalam bagian-bagian yang disebut: Membran, Mitochondria, Lysosome, Golgi Apparatus, Endoplasmic Reticulum, Nucleus (inti sel), Micro Tubes, Ribosome, Vacuole, dan Pinocytic Vesicles. Masing-masing bagian sel tersebut mempunyai sistem jaringan yang rumit, kompleks dan canggih. Bahkan, di dalam nucleus (inti sel) yang merupakan otak pengatur seluruh sistem yang bekerja dalam sel terdapat kromosom yang di dalamnya menyimpan "bank data" raksasa dengan kapasitas sangat tinggi dalam rantai-untai ganda DNA (Deoxyribo Nucleic Acid atau Asam Deoxiribo Nukleat). Rantai-untai ganda DNA ini menyerupai rantai spiral yang tersusun atas empat molekul yang berbeda, yaitu Adenine, Thymine, Cytosine, dan Guanine. DNA berfungsi untuk mengkodekan ratusan ribu informasi genetika. Untai genetika ini menyimpan perintah atau pesan berupa kode-kode kimiawi, yang harus dilakukan oleh sel-sel di mana untai genetika itu berada. Jika ia berada di dalam sel otak, maka ia memiliki perintah-perintah yang berbeda dengan sel-sel darah, atau juga berbeda dengan sel-sel tulang. Perintah itu sangat khas, sesuai dengan jenis selnya. Ada ribuan atau bahkan jutaan perintah yang tersimpan di dalam untai genetika suatu sel. Di dalam untai genetika sel rambut ada perintah untuk membuat zat-zat kimiawi yang berfungsi untuk mewarnai rambut menjadi hitam, merah, putih atau pirang. Singkatnya, satu sel saja mempunyai kerumitan dan kecanggihan yang luar biasa. Dan, tidak bisa tidak, kecanggihan sempurna di tingkatan sel tersebut membuktikan bahwa ada "Individu Cerdas" yang mendesain rancang bangunannya. Tidak mungkin sel mampu berfikir mandiri secara instan dan simultan untuk menyusun sebuah sistem yang super canggih tersebut.

Hasil observasi COBE dan temuan mutakhir Biologi-Molekuler menunjukkan fakta ilmiah bahwa kehidupan ini ada dari ketiadaan dan tersusun dalam sebuah sistem jaringan yang rapi, terukur, rumit, dan canggih. Hal ini membuktikan bahwa tidak mungkin materi ada dengan tiba-tiba dan terukur rapi tanpa adanya proses penciptaan, dengan kata lain, pasti ada "tangan-tangan tak tampak" (the invisible hands) yang mencipta, mendesain dan mengatur seluruh alam semesta ini, Dia-lah Tuhan. Begitu cerdas dan 
canggihnya Tuhan dalam bekerja, sampai-sampai seorang fisikawan dan kosmolog termasyhur abad ke-20, Albert Einstein berujar: "God doesn't play dice" (Tuhan tidak sedang bermain dadu). Artinya, dengan kedalaman dan keluasan ilmu-Nya, Tuhan bersungguh-sungguh (baca: tidak bermain-main) dalam mendesain dan mengukur ciptaan-Nya.

Berbeda dengan zeitgeist ilmu pengetahuan modern era abad ke-16 sampai abad ke-19 yang anti-Tuhan, perkembangan ilmu pengetahuan dewasa ini bergerak menuju satu access point yang semakin sadar bahwa Tuhan itu ada. Dia bersifat Absolute, Distinct, dan Unique.

\section{Peradaban Intelektual Muslim Abad Ke-21: Keterpaduan Intelektual dan Spiritual}

Perkembangan kekinian ilmu pengetahuan menyadarkan para ilmuan tentang sebuah fakta bahwa intelektual dan spiritual adalah dua hal yang terpadu, tak dapat dipisah-pisahkan. Menghilangkan atau mengabaikan spiritualitas dalam ranah ilmu pengetahuan berarti melakukan desakralisasi keilmuan. Hal ini menjadikan ilmu pengetahuan, sekadar lahan untuk melakukan trial and error games, tanpa ada usaha untuk menemukan kebenaran sejati dan karenanya bersifat sakral. Desakralisasi keilmuan atau cara berpikir ini sudah barang tentu secara langsung berdampak pada desakralisasi hingga tata kehidupan yang lebih luas, seperti yang terjadi di Barat pada abad ke16 hingga abad ke-21 ini. Singkatnya, tanpa spiritualitas ilmu pengetahuan menjadi sekular (the secularization of reason or knowledge), yang berimplikasi menimbulkan sekularisasi pada alam dan kehidupan (the secularization of the cosmos and life). Seyyed Hossein Nasr menyatakannya dengan: "the desacralization of knowledge was related directly to the descralization of cosmos" (Nasr, 1989: 45).

Usaha sekularisasi keilmuan ini ternyata tidak membawa manusia modern pada tata kehidupan yang lebih baik. Perkembangan keilmuan yang masif dan terspesialisasi, alih-alih memberi penjelasan banyak menimbulkan kekaburan konsepsi. Hal inilah yang dikeluhkan oleh Max Scheeler sebagai berikut:

"Tak ada periode lain dalam pengetahuan manusiawi, dimana manusia semakin problematis bagi dirinya sendiri, seperti pada periode kita ini. Kita punya antropologi ilmiah, antropologi filosofis, antropologi teologis yang tak saling mengenal satu sama lain. Tapi kita tak mempunyai gambaran yang jelas dan konsisten tentang manusia. Semakin bertumbuh dan banyaknya ilmu-ilmu khusus yang terjun mempelajari manusia, tidak menjernihkan konsepsi kita tentang manusia malah sebaliknya semakin membingungkan 
dan mengaburkannya".

Pernyataan Scheeler di atas adalah sebuah ironi. Manusia sebagai satu-satunya makhluk berakal di muka bumi, ternyata belum juga mampu memahami dirinya sendiri. Pertanyaannya adalah bagaimana mungkin kita mampu menjelaskan konsepsi tentang kosmos dan segala isinya, sementara konsepsi tentang diri kita sendiri belum mampu dijelaskan? Inilah ironi yang sekarang terjadi di dunia keilmuan. Oleh karena itu ilmu pengetahuan harus memadukan potensi intelektual dan spiritual yang dimiliki manusia. Keterpaduan intelektual dan spiritual akan menghasilkan ilmu pengetahuan yang mampu menjernihkan konsepsi kita tentang manusia. Asal usul dan tujuan hidup manusia yang selama ini masih dalam perdebatan bisa dijelaskan dengan baik. Sebaliknya, meninggalkan spiritualitas dalam ranah keilmuan berarti kita mendorong terjadinya kriminalisasi ilmu pengetahuan yang berujung pada runtuhnya peradaban; sebuah kehidupan yang mengaburkan tuntunan moral dan etik.

Apa yang telah kita diskusikan di atas mempertegas bahwa salah satu tugas intelektual muslim pasca modern adalah mengkonstruksi ulang paradigma keilmuan dengan kembali menempatkan Tuhan sebagai poros utama pemikiran. Tuhan, yang telah habis-habisan dikerdilkan eksistensinya oleh kaum intelektual Barat, harus kembali dihadirkan dalam seluruh aspek kehidupan manusia, termasuk dalam dunia keilmuan.

Bagi para cendekiawan muslim, hal ini merupakan tantangan sekaligus harapan untuk mengembangkan keilmuan berasaskan pada pancaran wahyu. Dalam perspektif yang lebih luas, ilmu pengetahuan adalah fondasi utama dan pertama dalam membangun sebuah peradaban. Ilmu pengetahuan yang didasarkan pada empirisme, seperti telah nyata dieksperimenkan oleh intelektual Eropa, menghasilkan sebuah peradaban inderawi, yang saat ini sedang menuju pada titik nadir keruntuhannya. Sementara itu, ilmu pengetahuan yang berasaskan pada pancaran wahyu dan renungan-renungan abstrak akan menghasilkan bangunan peradaban ideasional. Di sinilah tantangan berat sekaligus harapan yang diemban dan diharapkan dari kaum cendekiawan muslim.

Transformasi atau lebih tepatnya pembaharuan paradigma keilmuan dari empirisme menuju perenungan dan pengalaman spiritual merupakan jihad intelektual yang harus dilakukan sejak sekarang oleh para intelektual muslim. Sejatinya, tugas ini telah dirintis sejak Nabi Adam dan disempurnakan oleh Nabi Muhammad SAW. Para Nabi jika dicermati lebih teliti sesungguhnya adalah para pembaharu keilmuan yang menjadikan Allah sebagai the real god 
sekaligus sebagai konstanta keilmuan. Kalimat tauhid "Tidak ada Ilah selain Allah,” memberikan implikasi bahwa pemegang kebenaran/keilmuan sejati adalah Allah, Tuhan yang satu. Allah sendiri menegaskannya dalam al Quran (al An' am: 59) sebagai berikut:

"Dan pada sisi Allah-lah kunci-kunci semua yang ghaib, tak ada yang mengetahuinya kecuali Dia sendiri, dan Dia mengetahui apa yang di daratan dan lautan dan tiada sehelai daun pun yang gugur melainkan Dia mengetahuinya (pula), dan tidak jatuh sebutir biji pun dalam kegelapan bumi dan tidak sesuatu yang basah atau kering, melainkan tertulis dalam kitab yang nyata (Lauh Mahfuzh)".

Untuk mendapatkan kebenaran sejati maka manusia harus bersinggungan atau mendekatkan dirinya kepada Allah al Haq. Dengan berinteraksi secara lebih dekat akan dianugerahi oleh Allah sebagian (baca: setetes) dari ilmu-Nya. Intensitas interaksi intelektual-spiritual dengan Allah adalah merenungi tanda-tanda penciptaan langit dan bumi dan segala yang ada di dalamnya secara sungguh-sungguh dan dengan pikiran yang mendalam. Manusia seperti inilah yang dijuluki oleh al Quran sebagai Ulil Albab (ali Imran: 190-191).

Sesungguhnya dalam penciptaan langit dan bumi, dan silih-bergantinya malam dan siang terdapat tanda-tanda bagi orang yang berakal (Ulil Albab). Yaitu orang-orang yang mengingat Allah sambil berdiri atau duduk atau dalam keadaan berbaring dan mereka merenungi (tafakur) tentang penciptaan (kejadian) langit dan bumi (seraya berkata): "Ya Rabb kami, tiadalah Engkau menciptakan ini dengan sia-sia, Maha Suci Engkau, maka peliharalah kami dari siksa neraka".

Dalam bahasa lain, kebenaran ilmu hanya diberikan oleh Allah kepada hamba-hamba-Nya yang bersungguh-sungguh secara tulus penuh kerendahan diri mendekat kepada-Nya. Di hati mereka tertanam rasa takut kepada Allah dan menariknya, anugerah ini hanya Allah berikan kepada orang yang berilmu.

"Sesungguhnya yang takut kepada Allah di antara hamba-hamba-Nya hanyalah ulama (orang yang berilmu, cendekiawan atau intelektual-pen:)" (QS Fathir: 28).

Hal inilah yang membedakan intelektual muslim dengan non muslim. Secara sederhana, kerangka dasar paradigma keilmuan intelektual muslim dapat disimak dalam gambar 2.

Pada gambar 2 jelas berbeda dengan epistemologi Barat yang lebih mengandalkan penelitian atau observasi empiris tanpa mau membedahnya dengan teks-teks kitab suci. Hal ini tidaklah berlebihan karena dalam tradisi historis Barat, agama telah dianggap gagal mengemban misi keilmuan. Pada masa abad pertengahan, ketika dogma gereja sedang kuat-kuatnya menghegemoni Eropa, Eropa tenggelam dalam kubangan abad kegelapan. Renaisans dan Humanisme, jika ditelusuri lebih jauh, tidak lebih dari usaha kaum terpelajar 
Eropa untuk mengebiri peran dan eksistensi gereja.

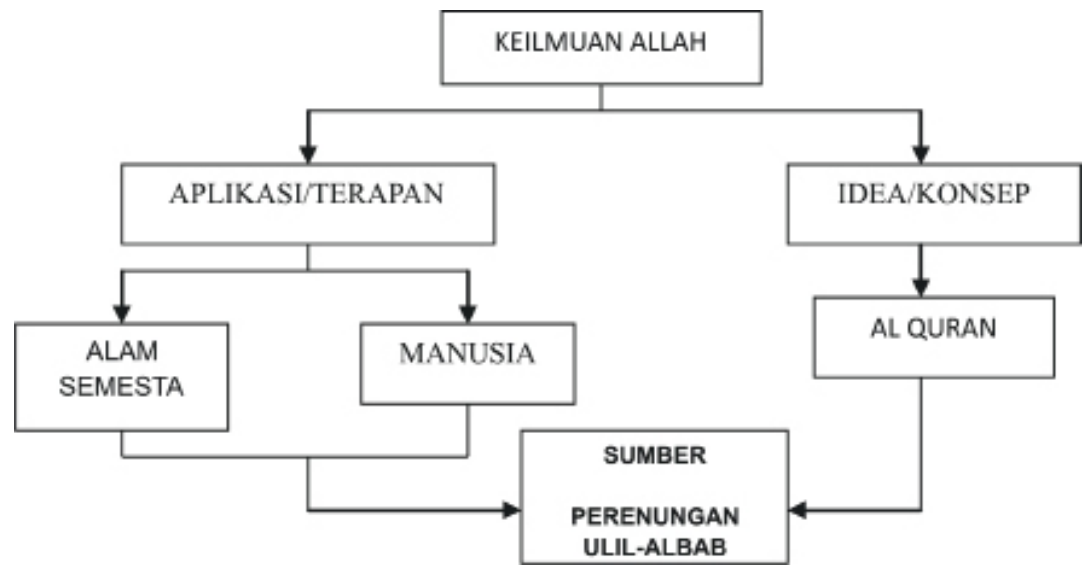

Gambar 2. Diagram kerangka dasar paradigma keilmuan intelektual Muslim

Singkat kata, dari uraian di atas, kita bisa membandingkan dua bingkai keilmuan yang saling bertolak belakang, yakni antara Tauhidisme ws Humanisme, antara Holistik vs Reduksionisme. Perbandingan ringkas kedua bingkai keilmuan ini dapat disimak dalam tabel berikut:

Tabel 1. Perbandingan bingkai keilmuan Islami versus Barat

\begin{tabular}{|c|c|c|}
\hline & ISLAMI & BARAT \\
\hline Epistemologi & Wahyu (al Quran) & Literatur atau Pendapat Pakar \\
\hline Metodologi & $\begin{array}{l}\text { Perenungan atau Tafakur } \\
\text { terhadap ayat-ayat } \\
\text { Quran + Hadits + Alam } \\
\text { (mengelaborasikan aqal } \\
\text { \& hati atau intelektual \& } \\
\text { spiritual) }\end{array}$ & $\begin{array}{l}\text { Studi Pustaka atau Penelitian } \\
\text { Empiris atau Pengandaian- } \\
\text { pengandaian ilmiah (asumsi, } \\
\text { hipotesis, paradigma) }\end{array}$ \\
\hline Aksiologi & $\begin{array}{l}\text { Penuntasan masalah } \\
\text { manusia }\end{array}$ & $\begin{array}{l}\text { Pemenuhan Kebutuhan atau } \\
\text { keinginan manusia }\end{array}$ \\
\hline Sifat & $\begin{array}{l}\text { 1. Monotafsir/constant } \\
\text { 2. Universal } \\
\text { 3. Holistik } \\
\text { 4. Objektif } \\
\text { 5. Pasti }\end{array}$ & $\begin{array}{l}\text { 1.Multitafsir/senantiasa penuh } \\
\text { perubahan } \\
\text { 2. Partikular } \\
\text { 3. Reduksionisme } \\
\text { 4. Subyektif } \\
\text { 5. Relatif }\end{array}$ \\
\hline Kerangka Berfikir & $\begin{array}{ll}\begin{array}{l}\text { Lateral-Elaboratif (Fuzzy } \\
\text { Logic) }\end{array} & \end{array}$ & $\begin{array}{l}\text { Horisontal \& Trial-Error (Uji- } \\
\text { Coba) }\end{array}$ \\
\hline
\end{tabular}




\begin{tabular}{|l|l|l|}
\hline Sudut Pandang & Esensi-Hakikat (Allah) & Fenomena-Empiris \\
\hline Gagasan Dasar & $\begin{array}{l}\text { 1. Tauhid } \\
\text { 2. Mendalam-meluas } \\
\text { 3. Masa lalu, sekarang dan } \\
\text { masa depan }\end{array}$ & $\begin{array}{l}\text { 1. Humanisme } \\
\text { 3. Meluas }\end{array}$ \\
\hline Out-Put & $\begin{array}{l}\text { Kedamaian hati \& } \\
\text { lingkungan/kestabilan alam- } \\
\text { semesta }\end{array}$ & $\begin{array}{l}\text { Gejolak hati \& lingkungan/ } \\
\text { kerusakan alam-semesta di } \\
\text { mana-mana }\end{array}$ \\
\hline $\begin{array}{l}\text { Peradaban } \\
\text { (Pitirim Sorokin) }\end{array}$ & Ideasional (Qurani) & Inderawi \\
\hline
\end{tabular}

Secara historis, bingkai keilmuan yang ditawarkan Islam menemukan momentum untuk tumbuh berkembang menjadi peradaban agung ketika Muhammad SAW melakukan hijrah ke Madinah. Di Madinah inilah, konsepsi Tauhidisme benar-benar dipraktikkan dalam kehidupan sehari-hari. Nabi Muhammad SAW berhasil mematerialkan gagasan-gagasan al Quran dalam tata kehidupan di Madinah secara sempurna. Dalam bahasa lain, masyarakat Madinah adalah model konkret sebuah bangunan peradaban agung yang berasakan pada Tauhidisme. Kemapanan intelektual dan spiritual menghasilkan ketentraman, persaudaraan dan toleransi di antara penduduk Madinah, yang belum pernah terjadi pada masa-masa sebelumnya. Bahkan, imperium Romawi dan Persia yang merupakan dua kekuatan adi kuasa pada masa itu tidak berhasil menciptakan peradaban semapan dan seagung peradaban Madinah.

Apa yang dipraktikkan Muhammad SAW di Madinah merupakan titik balik kebangkitan Islam dan umat manusia. Segera setelah masyarakat Madinah mencapai kemapanan peradaban Islam pun berkembang pesat menyebar ke empat penjuru mata angin dunia. Tidak kurang dari $1 / 5$ penduduk dunia dewasa ini telah memeluk Islam dan setidaknya seluruh dunia saat ini telah mengenal Islam. Diperkirakan terdapat 1,2 milyar umat Islam di dunia sekarang ini, satu dari lima orang di planet ini adalah muslim dan Islam mungkin adalah agama dunia yang paling pesat perkembangannya”. Sementara itu, dengan nada yang nyaris sama, Martin E Marty, dalam pengantarnya untuk buku Health and Medicine in The Islamic Tradition: Change and Identity, menyatakan:

“...Wilayah Islam berbatasan dengan wilayah Kristen, bukan berbaur.

Perjumpaan keduanya di kedua ujung Laut Tengah selalu diwarnai konflik dan kesalahpahaman".

Demikianlah publik cenderung berpikir. Memang benar bahwa keyakinan kaum muslim telah melahirkan sebuah dunia baru. Pada pertengahan abad ke-20, 
satu dari tujuh penduduk di dunia seorang muslim. Tiga perempat abad kemudian, dari setiap lima orang penduduk ada satu orang muslim, atau mempunyai nama muslim. Perubahan ini adalah akibat dari pertumbuhan penduduk dan juga upaya penyebaran Islam secara besar-besaran. Kebanyakan penyebarluasan Islam berlangsung bukan dengan semangat ala kadarnya, melainkan dengan gairah yang agresif. "Fundamentalisme Islam" pun menjadi istilah yang lazim.

Kemapanan peradaban Madinah merupakan cikal bakal keagungan peradaban Islam yang telah menembus ke hampir seluruh dunia. Oleh karena itu, orientasi intelektual yang menjadi tanggung jawab muslim adalah membedah prinsip-prinsip peradaban Madinah untuk direkonstruksikan pada kehidupan sekarang. Hal ini penting, karena selama kemapanan peradaban ala Madinah belum bisa terwujud, sangat sulit bagi kaum muslim untuk berbicara banyak dalam tataran peradaban dunia abad ke-21.

\section{Simpulan}

Jika pada masa awal Islam, jihad akbar yang diemban intelektual muslim adalah mengikis habis pola pandang jahiliyah yang berpusat pada pemujaan berhala, maka jihad akbar intelektual muslim dewasa adalah merekonstruksi pola pandang keilmuan yang saat ini terlalu bersifat empiric minded. Tanggung jawab intelektual muslim dewasa ini adalah menghadirkan Tuhan yang satu dalam diskursus-diskursus keilmuan. Allah al Haq adalah pemegang kuncikunci keilmuan dengan al Quran al Karim sebagai wujud konseptualisasi dari keagungan ilmu-Nya. Untuk itu, al Quran harus dijadikan sebagai sumber keilmuan yang selalu hidup.

\section{Daftar Pustaka}

Capra, Fritjof. 2000. Titik Balik Peradaban (Sains, Masyarakat dan Kebangkitan Kebudayaan). Jogjakarta: Bentang Budaya.

Depag RI. 1993. Al Quran dan Terjemahannya. Edisi baru. Jakarta.

Denton, Michael. 1986. Evolution: A Theory in Crisis. London: Burnet Books.

Lauer, Robert H. 1989. Prespektif tentang Perubahan Sosial. Jakarta: Bina Aksara.

Madjid, Nurcholis. 1995. Islam Agama Kemanusiaan, Membangun Tradisi dan Visi Baru Islam Indonesia. Jakarta: Paramadina.

Marx, Karl. 2000. Contribution to The Critique of Hegel's Philosophy of Right, 
termuat dalam On Religion, 1957 (Ramly, Andi Muawiyah, Peta Pemikiran Karl Marx [Materialisme Dialektis dan Materialisme Historis]. Yogyakarta: LkiS.

Nasr, Seyyed Hossein. 1989. Knowledge and the Sacred. New York: State University of New York Press.

Saunders, JJ. 1994. A History Medieviel Islam, dalam John L Esposito, Ancaman Islam Mitos atau Realitas. Bandung: Mizan.

Watt, W. Montgomerry. 1972. The Influence of Islam on Medieaval Europe. Edinburg: University Press. 